\title{
Multiculturalism and Interfaith Harmony Forum Activies
}

\author{
H K Kewuel ${ }^{1}$, I Khasanah'2, Y Fajar ${ }^{3}$ \\ ${ }^{1,2,3}$ Universitas Brawijaya \\ \{hipopegan@ub.ac.id ${ }^{1}$,hasanah_rahendy@yahoo.co.jp²,yusri_fajar@ub.ac.id ${ }^{3}$ \}
}

\begin{abstract}
Multiculturalism is inevitable everyday life. Preparing the community for multiculturalism is essential to maintain decent life quality. However, one question urges, who is responsible for such duty? In one nation, the government will be responsible for managing the governance including multiculturalism situation. The Indonesian government has prepared the community for multiculturalism since the early age of the nation through Pancasila. Such realization was also arranged in the Joint Decree of 2006 by the Minister of Religious Affairs and Minister of Internal Affairs which giving responsibility to Head of Regionals to regulate the adjustment of standard living order. This research focused on the role of Head of Regionals regarding the realization of the regulations. The ethnographical method was employed to discover the role and participation of each party.
\end{abstract}

Key Words: Good Governance, Anthropology Studies, Interfaith Harmony Forum, Multiculturalism

\section{INTRODUCTION}

Since the early age of Indonesia, the founding fathers had arranged the policies of religious matters as in the first principle of Pancasila, Article 29 section 2, Constitution of the Republic of Indonesia 1945, and further operational system is regulated in a Joint Decree of Minister of Religious Affairs and Minister of Internal Affairs Number 1 of 1969 and renewed in a Joint Decree of Minister of Religious Affairs and Minister of Internal Affairs Number 9 of 2006 / Number 8 of 2006.

Within the Decrees, it has been arranged the details as in the following; 1) Protecting harmony among the diverse religious community. 2) Empowering Interfaith Harmony Forum. 3) Establishing houses of worship. The arrangements become the responsibility of the Head of Regional. However, how effective is the realization of these arrangements? Have the arrangements of Joint Decrees of 2006 applied effectively and efficiently? Are religious matters and programs such as forum discussion and living in harmony as arranged in Joint Decrees of 2006 realized properly? How are the circumstances among religion diverse community? How is the realization of the house of worship establishment according to Joint Decree of 2006 ?

Anthropology of religion is a study that specifically examines human or their mind, attitude, and behavior in relation to their faith upon a higher power within formal religions known as God [1]. Anthropology of religion in its development is not merely on the relation of human and God, but also the relation of human to other humans as well as the environment. Therefore, 
the anthropology of religion is not only theoretically beneficial but also practically benefit human nature.

One of the certain matters in living among the religiously plural community is the encouragement to have dialog and harmony within the community [2]. Anthropology is a study of human nature to obtain thorough information regarding human diversity [3]. With that being said, Anthropology is one of the social sciences that not merely focuses on what is seen, yet it focuses more on what is hidden. Anthropology works through searching, revealing, and analyzing the roots of issues in every social phenomenon. In conclusion, Anthropology concerns on problems within the society based on the complication.

Good Governance concept was applied as one of the keys to overcoming the monetary crisis in 1997 through innovative policies both in the private and public sectors [4]. It was not merely depending on the government's policies, but also involving other non-government parties which struggled altogether without dominating one another. Anthropology is inseparable from other science fields since all of the other sciences are based on human from various angles. For example, is politics, in choosing a leader, people tend to seek for the background history, religion, and culture of the candidates. This is the field of anthropology science. The negligence, in this case, has spawned allegations of government programs as programs that are only for the sake of spending money and not for the sake of human development. There are three core values of development; the value of sufficiency which is the ability to fulfill basic needs, the value of identity which is the ability to be true to oneself, the value of freedom from being enslaved which is the ability have a choice [5].

Religious pluralism in its effort for treatment needs interference from the country in order to guarantee harmony among a peaceful diverse community. The value of freedom in everyday life becomes an essential matter primarily to ensure the security and freedom of the adherents of religions to carry out their religious rules. It is at once to affirm that freedom of religion is one of the most fundamental things of a man. Freedom of religion is originated directly from God and cannot be given by any country or community. Hence, government by any means cannot interfere on the internal matter of religion other than its traffic and system which provide space for each religion development. Government is also expected to emphasize the constitutional assurance of people's religious freedom.

Along with the firm anthropological discussion, the government will step a milestone on the effort of protecting peace and equality among the community. People, James, Bailey, dan Garrick [6] confirmed that anthropology in practice roles a vital part of managing problems of the world, such as population and poverty. Furthermore, it is stated that in many cases, anthropologists would stand as a lawyer that struggle to manage problems in living order. With the ethnographic abilities of various cases in society, anthropologists veiled in the defense function. In this sense, anthropologists perform particular functions to help society.

Castells [7] stated that identity politic is a part of the individual's participation in social life that is more determined by one's culture and psychological situation. Identity is the necessary construction process of a person's culture and psychoculture that gives meaning and purpose to their own lives which formed through internal dialogue and social interaction. This process is related to the formation of group identity.

\subsection{Research Method}

This research was conducted in City/Regency of Malang Raya located in East Java. Ethnographic research on the practice of religious harmony in the City/Regency of Malang Raya was expected to provide qualitative data to determine the level of realization of Interfaith 
Harmony Forum programs in this region. Supported by the quantitative data of Interfaith Harmony Forum activities of City/Regency of Malang Raya, the qualitative primary data was used to see the extent to which the implementation of the Joint Decree of 2006 has been applied and beneficially affected the people. This research was a qualitative research which was also interdisciplinary religious research since it examined the life of religions in the praxis level. The data of this study were collected through observation and in-depth interview. Qualitative research data can be collected in several ways; field observations, interviews, or through written documents already possessed by informants. Furthermore, according to Spreadly [8], the informant is determined by selecting the key informant, the person who influences the community. Also, a random search of informants was conducted in this study by using a snowball sampling technique, especially in digging information about the benefits of Interfaith Harmony Forum programs that beneficially affected various communities.

Data collection process includes 1) Participation and direct observation with the community to obtain data regarding their involvement in Interfaith Harmony Forum programs. 2) In-depth interviews with some key informants to get detailed information about the ins and outs of Interfaith Harmony Forum program development. 3) Focus Group discussion (FGD) with the Interfaith Harmony Forum officials of Malang City and the leaders of each religion. Secondary data was obtained in several ways. 1) Documentation and reference studies related to this research. 2) Publication and monographic data about Interfaith Harmony Forum activities in Malang.

Data analysis method has been started since the data collection stage up to the writing stage, it can even be said that the process of data analysis has been done throughout the research process. According to Cresswell [9], data analysis has started from field data collection (interview, transcribing the interview, scanning written texts thoroughly, classifying data, as well as describing data pattern). Primary data was approached with a qualitative perspective to provide a detailed and precise illustration of the information needed in the development and narrowing of research.

\subsection{Result and Discussion}

\subsubsection{Physical Conditions of the Organization}

Interfaith Harmony Forum is an organization formed at the regional level to assist the duties of the Head of Region in realizing the harmony of religious life in each region. It is done considering the importance of harmonious living atmosphere at the community level as one of the key factors to support the development process in the region. This forum was established by the community, fully supported by the government and, spread across all of the City/Regency in Indonesia. Thus, this forum is considered important as a strategic forum.

The Office is Hidden in the Back Area. The first impression, Interfaith Harmony Forum logo was installed and clear in front, but the office is hidden away behind the office complex. The building was simple and tended to be small for a regional governance office. According to the Interfaith Harmony Forum official named Dani, some administrators have a business or other interests outside the interests of Interfaith Harmony Forum of Malang City.

The writers had a chance to scan the room during the interview. There was a board with a black marker and there were agendas of Interfaith Harmony Forum of Malang City. One of the writings the writer noted was a visit to Interfaith Harmony Forum of Salatiga, Central Java. Looking at the agenda, the writers were reminded of the survey results of The Wahid Institute which nominated Salatiga City as the most tolerant city in Indonesia. 
There is also a display cabinet in which there are several souvenirs from various institutions. In addition to the blackboard, in the room, there is also a display cabinet in which there are several souvenirs from various institutions. It was a sign that Interfaith Harmony Forum of Malang City has partnered with many universities or institutions to improve their programs. Some charters were attached on the wall, it was given as a form of gratitude to Interfaith Harmony Forum Malang City who attended the event as a guest speaker.

Dani explained that in every period, there must be a program implemented by Interfaith Harmony Forum of Malang City. Each period lasts for five years of service. One of the programs carried out in 2016 was a survey on the harmony of religious communities in Malang City. The survey was conducted by gathering youth, including youths belonging to religious communities. The survey conducted in 2016 was not yet completed and was continued in 2017.

The program that is done every five years is called Strategic Plan (Renstra). Renstra will be reported to the government and the Interfaith Harmony Forum Central in order to arrange further policies. Not only coordinating with Interfaith Harmony Forum of East Java, but Interfaith Harmony Forum Malang City is also coordinating with Bangkesbangpol Malang City. It is because Interfaith Harmony Forum of Malang City is under Bangkesbangpol supervision. Therefore, every activity is monitored by Bangkesbangpol. Bangkesbangpol in Interfaith Harmony Forum of Malang City roles as the advisor.

Nameless and Hidden Inside a Religious Affairs Building. Further investigation brought the writer to Interfaith Harmony Forum of Malang Regency which according to information was located on Jalan Raya Pakisaji Number 166. It turned out that the building was BNN Malang Regency office, and Interfaith Harmony Forum of Malang Regency had moved to Islamic Centre in Kanjuruhan Stadium in Kepanjen. Once the writer arrived at the Islamic Center, it took a long time to find the Interfaith Harmony Forum office since it was located in one of the rooms there.

Eventually, the writer found the room. It had a glass door, and the condition was better than Interfaith Harmony Forum Malang City Office. However, both offices have similarities such as hidden and far from the community. Even though Interfaith Harmony Forum Malang Regency Office looked better, the office seemed to be temporary. Routines in Interfaith Harmony Forum Malang Regency was only until 13.00 in the afternoon.

Hidden in a Glass Castle. After getting the information about the location of Interfaith Harmony Forum of Batu City Office, the writers went straight to Block Office. In the vicinity of the building, many people were wearing black and white clothes, it was assumed that they were the city hall officials. At the entrance, the writer asked the location of Interfaith Harmony Forum of Batu City Office to one of the officials who were there. It turned out the official did not know the location and instead directed us to the lobby. The official was confused for being asked about Interfaith Harmony Forum of Batu City Office, as if not knowing anything about the existence of Interfaith Harmony Forum. After a lot of confusions, there was another official who knew the location of Interfaith Harmony Forum of Batu City Office. The official then accompanied us to the office located on the second floor. The writers were struck by the conditions inside the building that was so clean, neat, and very beautiful. The floor of the building was grayish white which was shiny and clean, then on the side of the building, there was a lot of blooming orchids. The building was beautiful. After arriving at the front of the Interfaith Harmony Forum of Batu City Office room, again the writers were surprised because the room was closed, quiet as if without occupants. Then, the writers were directed to the National Unity and Politics Agency (Bangkesbangpol) office to ask for instructions on the procedure to meet the Interfaith Harmony Forum of Batu City. 
The officer just gave us a small paper (form) that listed the requirements the writers needed to complete to meet with the Interfaith Harmony Forum. With this pattern, the writers imagined how many procedures needed to communicate with the Interfaith Harmony Forum Batu City. On the other hand, the writers were also aware that Interfaith Harmony Forum of Batu City is under the authority of Bangkesbangpol, other than that the location of the office room was on the same floor, just it was not on the opposite. The writer did not fill out the form because the writer did not have a list of procedures the writer had to complete. In the end, the writers decided to go home with a little disappointment. On the other hand, the writers were delighted to find out that Interfaith Harmony Forum Batu City Office was located at the corner of the magnificent luxury building, Batu City Hall building.

Thus, the writers finally managed to visit Interfaith Harmony Forum offices in three areas of Malang. The lonely and hidden office of Interfaith Harmony Forum Malang City in the back of the building and other government offices; Interfaith Harmony Forum Office of Malang Regency that was found after a long and overwhelming journey; and Interfaith Harmony Forum Batu City Office located in a luxury building, Batu City Hall. The writers were not only puzzled by the roads and intricacies of locating the office, but also confused and shocked by the condition of every Interfaith Harmony Forum office in Malang City, Malang Regency, and Batu City. This condition temporarily gave us a rough idea of what and how Interfaith Harmony Forum in Malang physically. Concerning the content and quality of Interfaith Harmony Forum activities, whether to describe the idealism as stated in the Ministerial Decree 2 or not, it is discussed in the second part as follow.

\section{2 Interfaith Harmony Forum Concerns and Efforts}

As an effort to realize the Interfaith Harmony Forum idealism, Interfaith Harmony Forum administrators in each Province and Regency/City have work programs that are undoubtedly different from each other in accordance with the situation and condition of each region, as well as having the primary color of the same activity. Some of the relatively similar activities include socialization activities, Interfaith Harmony Forum idealism development activities, and mediation activities if there are problems with religious life in the community, such as the problem of building houses of worship, and so on.

Socialization. The socialization intended here refers more to the effort to introduce the Interfaith Harmony Forum to the society. According to several informants, socialization can be done in some ways, both formal and informal. However, this has not been running smoothly because of some obstacles. The first obstacle, according to most informants, is because the Interfaith Harmony Forum administrators that have not been too focused on the main task of Interfaith Harmony Forum development. Almost all of the administrators are taken from employees in government agencies and religious institutions who have been very busy with their main job so that their job in the Interfaith Harmony Forum just a formality to meet the organizational structure. That is also why there are no serious thinkers who want to develop the Interfaith Harmony Forum, including the socialization strategy and others (interview with Mr. Haris from Interfaith Harmony Forum Malang Regency).

Development activities of Interfaith Harmony Forum idealism and mediation role. It means that as a professionally managed forum, Interfaith Harmony Forum must have idealisms that should be developed in realizing the forum. It also presupposes that there are special programs established as a translation of the formal organization idealism. Thus, the organization does not just exist, but there is also evidence of its presence born of itself. The information from the informants clearly shows that Interfaith Harmony Forum has not made something as unique 
from the forum itself in realizing its task. For instance, it has not been seen that what program Interfaith Harmony Forum is doing to solve the establishment of houses of worship cases and others. Everything still follows the dynamic that occurs in the community without the typical position of Interfaith Harmony Forum. The forum is still in a position to find a secure position. If there is a turmoil in the establishment of houses of worship, for example, it is not the rule of the State that is fought for, but the compromise with the people which is more likely to take precedence [10].

\section{CONCLUSIONS}

The establishment of the Interfaith Harmony Forum in the Joint Decree of 2 Ministers year 1969, which was subsequently refined in the Joint Decree of 2 Ministers year 2006, is a more concrete form of translation of efforts to manage the diversity, particularly the diversity of religious life in Indonesia. In reality, the effort of managing the diversity of religious practices that have been instituted in the Interfaith Harmony Forum and operating at the provincial to regency/city levels has not shown the maximum result.

Such matter is because Interfaith Harmony Forum still becomes an organization that has not yet finished with its internal organizational affairs. Interfaith Harmony Forum administrators are not formed in a spirit to creatively and independently strive to create a harmony of religious life. Interfaith Harmony Forum administrators are still elected in a leadership pattern where there are just people who fill the organization's completeness formation. There is no professional orientation in handling this religious-labeled forum. It still accentuates label of religious figures without sufficient orientation to maximize the role of Interfaith Harmony Forum.

Such kind of leadership pattern in the organization has a long-term effect. The result of the research shows that the physical office of Interfaith Harmony Forum in Malang tends to be neglected and unclear even. Its administrators rarely come to the office and their coordination is almost always through the media, almost without a program. The program will be taken seriously if there is transparent funding. These two conditions indicate that Interfaith Harmony Forum has not yet become a professionally operated program. The proof of the unprofessionalism is seen by the absence of effort and intent to fight for a viable Interfaith Harmony Forum office. Similarly, this is reflected in the seriousness of the board to think about reliable programs and help to live a better life with society. There is an impression that Interfaith Harmony Forum only exists as a symbol that there is a forum or institution in Indonesia which is responsible for the affairs of religious life, but in fact, there is nothing to be proud of. The physical appearance exists, but there is no meaningful content.

Being aware of this kind of conditions of the Interfaith Harmony Forum, some suggestions may be delivered as follow; (a). The Interfaith Harmony Forum must be realized as a forum that has a strategic position in the diversity of religious life in Indonesia. (b). The growth of this kind of awareness will automatically encourage Interfaith Harmony Forum administrators to create a comfortable and conducive working situation to fight for what is needed by many people with different religious backgrounds. An appropriate Interfaith Harmony Forum office or workplace will be an impetus for the administrators and activists of religious harmony to fight for their idealism. (c). Such idealism struggle requires energetic people who are not only to fill positions but more to fight for something useful for many people. 


\section{REFERENCES}

[1] Hendropuspito, D., Sosiologi Agama, Yogyakarta dan Jakarta: Kanisius dan BPK Gunung Mulia, hal. 169, 1984

[2] Haviland, William, Antropologi (edisi terjemahan), Jakarta: Erlangga, hal. 7, 2002

[3] Mardiasmo, D., Barnes, P., dan Sakurai, Y., Implementation of Good Governance by Regional Governments in Indonesia: The Challenges dalam Brown, K., Mandell, M., Furneaux, C. dan Beach, S. (ed). Proceedings: Contemporary Issues in Public Management (IRSPM XII), Brisbane, Australia, p. 1-36, 2008

[4] Todaro, Michael P., Pembangunan Ekonomi di Dunia Ketiga (terjemahan, edisi-7), Jakarta: Erlangga, hal. 21-23, 2000

[5] Effendi, Johan, "Jaminan Konstitusi bagi Kebebasan Beragama di Indonesia", dalam Hidayat, 1998 Komaruddin dan Gaus, AF Ahmad, Passing Over: Melintasi Batas Agama, Jakarta: Gramedia, hal. 111-122

[6] Peoples, James dan Bailey, Garrick, Humanity: An Introduction to Cultural Antropology, 5 Singapore, Australia, Canada, Latin America: Thomson Learning Academic Resource Center, p. 378-398, 2006

[7] Castells, Manuel, The Pothe writer of Identity, Oxford, UK: Blackthe writerll Publishing Ltd, p. 6-7, 2010

[8] Spredley, James, P., Metode Etnografi, Yogyakarta: PT. Tiara Wacana, 1997

[9] Cresswelll, John, Riset Pendidikan: Perencanaan, Pelaksanaan, dan Evaluasi Riset Kualitatif dan Kuantitatif, Jakarta: Pustaka Pelajar, 2015

[10] K. Saddhono, "Cultural and social change of foreign students in Indonesia: The influence of Javanese Culture in Teaching Indonesian to Speakers of Other Languages (TISOL)." IOP Conf. Ser.: Ear. and Envi. Sci.. vol. 126 no. 1 IOP Publishing, 2018. 